\title{
Detection of macrolide and disinfectant resistance genes in clinical Staphylococcus aureus and coagulase-negative staphylococci
}

\author{
Tarek Zmantar ${ }^{*}$, Bochra Kouidhi, Hanene Miladi and Amina Bakhrouf
}

\begin{abstract}
Background: Staphylococcus aureus and Coagulase-negative staphylococci (CoNS) are a major source of infections associated with indwelling medical devices. Many antiseptic agents are used in hygienic handwash to prevent nosocomial infections by Staphylococci. Our aim was to determine the antibiotic susceptibility and resistance to quaternary ammonium compound of $46 \mathrm{~S}$. aureus strains and 71 CoNS.

Methods: S. aureus $(n=46)$ isolated from auricular infection and CoNS $(n=71), 22$ of the strains isolated from dialysis fluids and 49 of the strains isolated from needles cultures were investigated. Erythromycin resistance genes (ermA, ermB, ermC, msrA and mef) were analysed by multiplex PCR and disinfectant-resistant genes (qacA, qacB, and gacC) were studied by PCR-RFLP.

Results: The frequency of erythromycin resistance genes in S. aureus was: ermA $+7.7 \%$, ermB $+13.7 \%$, erm C $+6 \%$ and $m s r A+10.2 \%$. In addition, the number of positive isolates in CoNS was respectively ermA+ (9.4\%), ermB+ (11.1\%), ermC+ (27.4\%), and msrA+ (41\%). The MIC analyses revealed that 88 isolates (74\%) were resistant to quaternary ammonium compound-based disinfectant benzalkonium chloride (BC). 56\% of the BC-resistant staphylococcus isolates have at least one of the three resistant disinfectants genes (qacA, qacB and qacC). Nine strains (7.7\%) among the CoNS species and two S. aureus strains (2\%) harboured the three-qac genes. In addition, the gacC were detected in 41 strains.
\end{abstract}

Conclusions: Multi-resistant strains towards macrolide and disinfectant were recorded. The investigation of antibiotics and antiseptic-resistant CoNS may provide crucial information on the control of nosocomial infections.

Keywords: Staphylococcus aureus, Coagulase-negative Staphylococci, Multidrug resistance, qac

\section{Background}

The increasing number of infections caused by oxacillinresistant staphylococci makes glycopeptide antibiotics an important choice [1]. The significant prevalence of nosocomial infections caused by multi-resistant $S$. aureus and coagulase-negative staphylococci (CoNS) has been documented $[2,3]$. These species have the ability to survive in medical devices for months [4]. Resistance to erythromycin in staphylococci is usually associated with resistance to other macrolides. Three genes (ermA, ermB, and $\operatorname{erm} \mathrm{C}$ ) encoding methyltransferases responsible of resistance to macrolides, lincosamides and type $B$

\footnotetext{
* Correspondence: zmantar_t@yahoo.fr

Laboratoire d'Analyse, Traitement et Valorisation des Polluants de l'Environnement et des Produits, Faculté de Pharmacie, Monastir, Tunisia
}

streptogramins ( $\mathrm{MLS}_{\mathrm{B}}$ phenotype) by modification of the ribosomal target site have been found in staphylococci [5]. The msrA gene displays another mechanism of inducible resistance to erythromycin by encoding an ATP-dependent efflux pump [6]. On the other hand, macrolide efflux is affected by a membrane protein encoded by the mef gene [7]. Antiseptic agents include various compounds with different chemical structures [8]. The widespread use of quaternary ammonium compounds (QAC) in hospitals actually contributes to the emergence of disinfectant-resistant bacteria $[9,10]$. Epidemiological data on antiseptic susceptibility and the distribution of resistance genes are both useful for nosocomial infection control. In several staphylococcal species, qac-resistant genes have been identified [11-13]. 
Found in clinical staphylococci ( $q a c \mathrm{~A}, q a c \mathrm{~B}$, and $q a c \mathrm{C})$, these genes are generally carried by plasmids [14-16]. Some of these plasmids (pST6, pSK4, and pSK41) contain antibiotic resistance genes encoding resistance to gentamicin, penicillin, kanamycin, and tobramycine $[17,18]$. Multidrug resistance pumps have been recognized as mediators of a number of commonly used ammonium antiseptics and detergents [19]. The nearly identical $q a c \mathrm{~A} / \mathrm{B}$ gene is normally harboured by large plasmids [20,21]. The relation between qac resistance and penicillin resistance in human clinical staphylococci is quite prevalent [22].

In the present study, we examined the antibiotic susceptibility and resistance to quaternary ammonium compound-based disinfectant benzalkonium chloride (BC) of $46 \mathrm{~S}$. aureus strains isolated from auricular infection and 71 CoNS isolated from dialysis fluids and needles cultures. In order to examine the genetic drug resistance mechanisms, erythromycin resistance genes (ermA, erm $\mathrm{B}$, and erm $\mathrm{C}$ ) and macrolide efflux genes (msr A and mef) were analysed by PCR multiplex. In addition, quaternary ammonium resistance genes (qacA, $q a c \mathrm{~B}$, and $q a c \mathrm{C})$ were detected by PCR-RFLP.

\section{Methods}

\section{Biochemical characterization and antimicrobial susceptibility}

A total of 117 clinical staphylococcal strains were isolated from Kairouan, in central of Tunisia including $46 \mathrm{~S}$. aureus strains isolated from auricular infection and 71 CoNS strains isolated from dialysis fluid and needles from a dialysis service. All strains were identified using the Api ID32 Staph system (bioMérieux, Marcy l'Étoile, France) according to the manufacturer's recommendations and the results were read using an automated microbiological mini-Api (bioMérieux, Marcy l'Étoile, France). Each strain was tested for 18 antibiotics (penicillin, oxacillin, kanamycin, tobramycin, gentamicin, tetracycline, minocyclin, erythromycin, lincomycin, pristinamycin, fosfomycin, nitrofurantoin, pefloxacin, rifampicin, fusidic acid, vancomycin, teicoplanin and cotrimoxazol) using the ATB Staph system (bioMérieux, France) according to the manufacturer's specifications.

\section{Minimum inhibitory concentration determination}

The broth microdilution method was used to determine the minimum inhibitory concentration (MIC) of benzalchonium chloride (BC) (Acros organics, USA) (ranging from 0.5 to $256 \mu \mathrm{g} / \mathrm{ml}$, by serial twofold dilutions) against the tested strains as recommended by the Clinical and Laboratory Standards Institute (CLSI) [23]. An inoculum of $10^{4}-10^{5}$ cells $\mathrm{ml}^{-1}$ was used. The lowest concentration of antimicrobial agent totally preventing growth after $24 \mathrm{~h}$ was taken to be the MIC.

\section{Multiplex PCR for the detection of macrolide-resistance encoding genes}

Macrolide resistance genes erm A, ermB, erm C, $m s r \mathrm{~A}$, and mef were examined in all strains using multiplex PCR, as previously described [24,25]. Multiplex PCR assays were performed in $25 \mu \mathrm{l}$ PCR mixture 1 and mixture 2 . Mixture 1 contained a DNA template (50 ng), $100 \mu \mathrm{M}$ concentrations (each) of the four dNTPs, $1 \mathrm{U}$ of Go Taq DNA polymerase (Promega, Lyon, France), $5 \mu \mathrm{L}$ green Go Taq buffer (5X), 25 pM each of forward and reverse primers ermA, erm $\mathrm{C}$, and msrA (Table 1). The PCR mixtures were subjected to thermal cycling $\left(3 \mathrm{~min}\right.$ at $96^{\circ} \mathrm{C}$, followed by 30 cycles of $30 \mathrm{sec}$ at $95^{\circ} \mathrm{C}$ for denaturation, $30 \mathrm{sec}$ at $55^{\circ} \mathrm{C}$ for annealing extension, and extension at $72^{\circ} \mathrm{C}$ for $2 \mathrm{~min}$ ). A final elongation at $72^{\circ} \mathrm{C}$ for $10 \mathrm{~min}$ was achieved in a DNA thermal cycler (GenAmp PCR system 9700-Applied Biosystem Int., USA). For mixture 2 , the forward and reverse primers (25 pM) of genes ermB and mef were used. PCR products were analysed in agarose gel (1\%) electrophoresis in $1 \mathrm{X}$ Tris-borate-EDTA buffer (TBE) at $\mathrm{pH}$ 8.3. The amplification products were photographed and their size was determined using a 100 bp molecular size marker (Bio-Rad, France).

\section{Detection of qacA, qacB, and qacC genes by PCR-RFLP}

Multiplex PCR-RFLP analysis of the $q a c \mathrm{~A} / \mathrm{B}$ and $q a c \mathrm{C}$ genes was achieved as described by Sekiguchi et al. [26]. For the fragment $q a c \mathrm{~A} / q a c \mathrm{~B}$, the forward primer (corresponding to nucleotides 924-946) and the reverse primer (corresponding to nucleotides 1143-1124) produced 220 $\mathrm{bp}$. For the $q a c \mathrm{C}$ gene, the forward primer (nucleotides 73-97) and the reverse primer (nucleotides 321-302) produced 249 bp. PCR was performed in a $25 \mu \mathrm{l}$ reaction volume containing $50 \mathrm{ng}$ of extracted DNA, $5 \mu \mathrm{l}$ green Go Taq buffer (5X), $200 \mu \mathrm{M}$ each of deoxynucleoside triphosphates (dNTP), $25 \mu \mathrm{M}$ each of $q a c \mathrm{~A}, q a c \mathrm{~B}$, and qacC forward and reverse primers, $1 \mathrm{U}$ of GO Taq DNA polymerase (Promega, USA). Each PCR was performed in duplicate. The reaction mixtures were heated to $94^{\circ} \mathrm{C}$ for $5 \mathrm{~min}$ and were then subjected to 30 denaturation cycles at $94^{\circ} \mathrm{C}$ for $1.5 \mathrm{~min}$, annealing at $56^{\circ} \mathrm{C}$ for $0.5 \mathrm{~min}$ and extension at $72^{\circ} \mathrm{C}$ for $1.5 \mathrm{~min}$, ending with a final extension at $72^{\circ} \mathrm{C}$ for $10 \mathrm{~min}$.

Following PCR, the product was digested with $5 \mathrm{U}$ of $\mathrm{AluI}$ at $37^{\circ} \mathrm{C}$ for $90 \mathrm{~min}$ (Promega, France). Ten microlitres of treated product were analysed by gel electrophoresis in 3\% agarose gel in $1 \mathrm{X}$ Tris-borate-EDTA buffer (TBE, pH 8.3). The amplification products were photographed and their size was determined using a $25 \mathrm{bp}$ molecular size marker (Promega, USA). The qacB gene was expected to be digested into two fragments: a visible $176 \mathrm{bp}$ fragment and another fragment of $44 \mathrm{bp}$ which is invisible. Q Q acA and $q a c \mathrm{C}$ genes were not expected to be digested [26]. 
Table 1 List of primer used for the detection of genes encoding antibiotics and quaternary ammonium compound resistance

\begin{tabular}{|c|c|c|c|}
\hline Gene & Primer 5'-3' & Product Size pb & Reference \\
\hline ermA & $\begin{array}{l}\text { 5'-TAT CTT ATC GTT GAG AAG GGA TT-3' } \\
\text { 5'-CTA CAC TTG GCT TAG GAT GAA A-3' }\end{array}$ & 139 & [22] \\
\hline ermB & $\begin{array}{l}\text { 5'-CTA TCT GAT TGT TGA AGA AGG ATT-3' } \\
\text { 5'-GTT TAC TCT TGG TाT AGG ATG AAA-3' }\end{array}$ & 142 & [22] \\
\hline ermC & $\begin{array}{l}\text { 5'-CTT GTT GAT CAC GAT AAT TTC C-3' } \\
5^{\prime} \text {-ATC TIT TAG CAA ACC CGT ATT C-3' }\end{array}$ & 190 & [22] \\
\hline msrA & $\begin{array}{l}\text { 5'-TCC AAT CAT AGC ACA AAA TC-3' } \\
\text { 5'-AAT TCC CTC TAT TTG GTG GT-3' }\end{array}$ & 163 & {$[22]$} \\
\hline mef & $\begin{array}{l}\text { 5'-AGTATCATTAATCACTAGTGC-3' } \\
\text { 5'-TTCTTCTGGTACAAAAGTGG-3' }\end{array}$ & 348 & [23] \\
\hline qacA, qacB & $\begin{array}{l}\text { 5'-TCCTITTAATGCTGGCTTATACC-3' } \\
\text { 5'-AGCCKTACCTGCTCCAACTA-3' }\end{array}$ & 220 & [24] \\
\hline gacc & $\begin{array}{l}\text { 5'-GGCTTTTCAAAATTTATACCATCCT-3' } \\
\text { 5'-ATGCGATGTTCCGAAAATGT-3' }\end{array}$ & 249 & [24] \\
\hline
\end{tabular}

\section{Statistical analysis}

Statistical analysis was performed on SPSS v.13.0 statistics software. Pearson's chi-square ${ }^{-2}$ test was used to asses inter-group significance. In addition statistical significance was set at $\mathrm{P}<0.05$.

\section{Results}

\section{Biotyping and antimicrobial susceptibility}

In this study, $46 \mathrm{~S}$. aureus strains isolated from auricular infection were identified. In addition 71 CoNS were isolated and were subdivided into eight species: S. epidermidis $(\mathrm{n}=32)(45 \%)$ followed by S. hominis $(\mathrm{n}=10)(14.1 \%)$, S. haemolyticus $(\mathrm{n}=9)(12.7 \%)$, S. warneri $(\mathrm{n}=5)(7 \%)$, S. simulans $(\mathrm{n}=6)(8.5 \%)$, S. capitis $(\mathrm{n}=4)(5.6 \%)$, S. chromogenes $(\mathrm{n}=3)(4.2 \%)$, and S. equorum $(\mathrm{n}=2)(2.8 \%)$.

The results of the antibiotic susceptibility test confirmed the multi-resistance of 117 staphylococcal strains toward the 18 antibiotics mentioned previously. The majority of these strains were resistant to penicillin (91.1\%). The isolated strains were also resistant to kanamycin $(45.7 \%)$, tetracycline $(47.8 \%)$, erythromycin (37.7\%), lincomycin (21.2\%), fosfomycin (20.8\%), fusidic acid $(17.3 \%)$, pefloxacin (18.4\%), cotrimoxazol (24.3\%), teicoplanin $(10.5 \%)$, gentamicin $(13.4 \%)$, rifampicin (12.1\%), and tobraycin (16.8\%).

Oxacillin-resistant phenotype was found in 9 S. aureus (7.7\%) and 24 CoNS (20.5\%) isolated strains. All of the strains were susceptible to pristinamycin, nitrofurantoin, and vancomycin (Table 2 and 3).

\section{Resistance to disinfectants agents}

The 117 staphylococcus isolates were screened for QAC (BC) resistance. The strains were categorized as $\mathrm{BC}$ resistant or sensitive according to the BC MICs. Twenty four $(20 \%)$ isolates were considered BC highly resistant (BC MICs between 16 and $32 \mu \mathrm{g} / \mathrm{ml}$ ), 64 (54\%) isolates were resistant to $\mathrm{BC}$ (BC MICs between 4 and $8 \mu \mathrm{g} / \mathrm{ml}$ ), and $28(23 \%)$ strains were sensitive to BC (BC MICs $\leq 2$ $\mu \mathrm{g} / \mathrm{ml}) .117$ staphylococci isolates were analyzed for correlation between $\mathrm{BC}$ and antibiotic resistance (Figure 1). This analysis showed that the frequency of erythromycin resistance $71 \%$ and oxacillin resistance $84 \%$ was higher among the BC-resistant strains.

\section{Multiplex PCR for the detection of genes encoding macrolide resistance}

In this study we found that the incidence of the three erythromycin ribosomal methylase genes tested was 9 (7.7\%) strains of $S$. aureus contained ermA, 16 (13.7\%) strains harbored ermB gene and 7 (6\%) strains were positive for erm C in the total of 117 isolated strains (Figure 2A, B). Furthermore among the CoNS 11 (9.4\%) strains contained ermA. In addition, on the total of 117 isolated strains 13 CoNS strains carried the ermB gene, while 32 (27.3\%) were positive for $\mathrm{erm} \mathrm{C}$. The $m s r A$ gene was present in 12 (10.2\%) of $S$. aureus strains and in 48 (41\%) CoNS strains (Figure 2A). In contrast, the mef gene was absent in all the staphylococcal strains tested. Sixteen strains of S. epidermidis, eight strains of $S$. aureus and eighteen strains of CoNS were positive for the mecA gene, yet were susceptible to oxacillin. Furthermore, only nine strains of CoNS (7.7\%) and nineteen strains (16.2\%) of S. aureus were susceptible to erythromycin, those isolated did not contain any of the erythromycin-resistance genes tested. However, in five S. epidermidis strains (E7, E20, S23, S27, and S40), and in ten $S$. aureus stains, the ermA and erm $\mathrm{C}$ genes were not detected, although it was resistant to erythromycin (Table 2 and 3 ).

PCR-RFLP detection of qacA, qacB, and qacC genes

Among the tested $S$. aureus two strains (Sa22 and Sa23) carried the three $q a c$ genes ( $q a c \mathrm{~A}, q a c \mathrm{~B}$ and $q a c \mathrm{C}$ ) 
Table 2 Distribution of disinfectant and macrolide resistance genes in staphylococci

\begin{tabular}{|c|c|c|c|c|c|c|c|c|c|c|c|}
\hline & Samples & qacA & $q a c \mathrm{~B}$ & qacC & $\mathrm{BC}^{\mathrm{b}}$ & mecA & ermA & ermB & ermC & $m s r A$ & Antibiotic \\
\hline \multirow[t]{32}{*}{ S. epidermidis } & E10 & + & - & + & 16 & + & - & + & + & + & $\mathrm{Oxa}^{\mathrm{S}}, \mathrm{Ery}^{\mathrm{S}}$ \\
\hline & E11 & - & - & + & 8 & + & - & + & + & + & $O x a^{R}$ \\
\hline & E13 & - & - & - & 4 & - & - & - & - & - & $O x a^{R}$ \\
\hline & E15 & - & - & + & 8 & + & - & + & + & - & $\mathrm{Oxa}^{\mathrm{R}}, \mathrm{Ery}^{\mathrm{R}}$ \\
\hline & E18 & + & - & + & 16 & + & - & - & + & + & Oxas, Ery $^{\mathrm{s}}$ \\
\hline & E20 & - & - & - & 2 & + & - & - & - & + & Ery $^{R}$ \\
\hline & E21 & + & - & + & 8 & + & - & - & + & + & $O x a^{R}$ \\
\hline & E24 & - & - & - & 8 & + & - & - & + & + & Ery $^{\mathrm{R}}$ \\
\hline & E4 & - & - & - & 4 & - & - & - & - & - & $O x a^{R}$ \\
\hline & E5 & - & - & - & 4 & - & - & - & - & - & $O x a^{R}$ \\
\hline & E6 & - & - & - & 2 & + & - & + & + & + & Oxas, Ery ${ }^{\mathrm{S}}$ \\
\hline & E7 & - & - & + & 8 & - & - & - & - & - & Ery $^{R}$ \\
\hline & E9 & - & - & + & 16 & + & - & + & - & + & $\mathrm{Oxa}^{\mathrm{S}}, \mathrm{Ery}^{\mathrm{S}}$ \\
\hline & $\mathrm{S} 12$ & - & - & + & 16 & - & - & - & - & + & Oxa $^{\text {S }}$, Ery $^{\text {S }}$ \\
\hline & S15 & - & - & + & 8 & + & + & + & + & + & Oxa ${ }^{R}$, Ery $^{R}$ \\
\hline & S16 & - & - & + & 8 & + & - & + & + & + & Oxa ${ }^{\mathrm{S}}$, Ery $^{\mathrm{S}}$ \\
\hline & $\mathrm{S} 2$ & - & - & + & 8 & + & - & - & + & + & Oxas, Ery ${ }^{\mathrm{S}}$ \\
\hline & S21 & + & + & + & 32 & + & + & - & + & + & $O x a^{R}$ \\
\hline & S22 & - & - & - & 8 & + & - & - & + & + & Oxa ${ }^{\mathrm{S}}$, Ery $^{\mathrm{S}}$ \\
\hline & S23 & - & - & - & 2 & + & - & - & - & + & Ery $^{R}$ \\
\hline & S25 & - & - & + & 8 & + & - & + & + & + & $O x a^{R}$ \\
\hline & S26 & - & - & + & 4 & + & - & + & + & + & Oxa ${ }^{R}$, Ery $^{R}$ \\
\hline & S27 & - & - & - & 2 & - & - & - & - & + & Ery $^{R}$ \\
\hline & S33 & - & - & - & 2 & + & + & - & - & - & Oxas, Ery ${ }^{\mathrm{S}}$ \\
\hline & S35 & - & - & - & 2 & - & - & - & - & - & Oxas Ery $^{\mathrm{S}}$ \\
\hline & S38 & - & - & & 4 & + & & - & - & & Oxas ${ }^{\mathrm{S}}$, Ery $^{\mathrm{S}}$ \\
\hline & $S 40$ & - & - & + & 8 & + & - & - & - & + & Oxa ${ }^{R}$, Ery $^{R}$ \\
\hline & $S 43$ & - & - & - & 2 & + & - & - & - & + & Oxas Ery $^{\mathrm{S}}$ \\
\hline & S48 & - & - & - & 2 & + & + & - & + & - & Oxa ${ }^{R}$, Ery $^{R}$ \\
\hline & S56 & - & - & - & 2 & + & - & + & + & + & Oxa ${ }^{R}$, Ery ${ }^{R}$ \\
\hline & S59 & - & - & - & 4 & + & - & - & - & - & Oxas, Ery ${ }^{\mathrm{s}}$ \\
\hline & S9 & + & + & + & 16 & + & - & - & + & + & Oxas, Ery ${ }^{\mathrm{S}}$ \\
\hline \multirow[t]{10}{*}{ S. hominis } & E17 & - & - & - & 16 & + & - & - & + & - & $O x a^{R}$ \\
\hline & E2 & - & - & - & 2 & - & - & - & - & - & Oxa ${ }^{\mathrm{S}}$, Ery $^{\mathrm{S}}$ \\
\hline & E27 & - & - & - & 2 & - & - & - & - & + & Oxas ${ }^{\mathrm{S}}$ Ery ${ }^{\mathrm{S}}$ \\
\hline & $\mathrm{S} 18$ & + & + & + & 16 & - & + & - & + & + & Oxas ${ }^{\mathrm{S}}$ Ery ${ }^{\mathrm{S}}$ \\
\hline & S3 & - & - & + & 8 & + & - & - & + & - & Oxa ${ }^{R}$, Ery $^{R}$ \\
\hline & S45 & + & & & 4 & + & - & - & - & - & Oxa ${ }^{R}$, Ery $^{R}$ \\
\hline & S50 & - & - & - & 4 & + & - & - & - & + & Ery $^{R}$ \\
\hline & S53 & - & - & - & 2 & + & - & - & - & + & Ery $^{R}$ \\
\hline & S54 & - & - & - & 2 & - & - & - & - & - & Ery $^{R}$ \\
\hline & S57 & + & - & + & 8 & + & - & - & + & - & $O x a^{R}$ \\
\hline \multirow[t]{2}{*}{ S. equorum } & E3 & + & - & + & 8 & + & - & - & - & + & Ery $^{R}$ \\
\hline & S6 & + & + & + & 16 & + & - & + & + & + & Oxa ${ }^{R}$, Ery $^{R}$ \\
\hline \multirow[t]{4}{*}{ S. capitis } & E25 & + & + & + & 32 & - & + & - & + & + & $\mathrm{Oxa}^{\mathrm{S}}, \mathrm{Ery}^{\mathrm{S}}$ \\
\hline & $\mathrm{S1}$ & + & + & - & 32 & + & + & - & - & + & Oxas ${ }^{\mathrm{S}}$ Ery ${ }^{\mathrm{S}}$ \\
\hline & S34 & + & - & + & 32 & - & - & - & - & + & Ery $^{R}$ \\
\hline & S49 & - & - & - & 8 & + & - & - & - & + & Oxas ${ }^{\mathrm{s}}$ Ery ${ }^{\mathrm{s}}$ \\
\hline \multirow[t]{3}{*}{ S. hemolyticus } & E16 & - & - & + & 8 & + & - & - & - & + & Ery $^{R}$ \\
\hline & E19 & + & + & + & 16 & + & - & - & - & + & Ery $^{R}$ \\
\hline & E22 & - & - & + & 8 & + & - & - & - & + & Ery $^{R}$ \\
\hline
\end{tabular}


Table 2 Distribution of disinfectant and macrolide resistance genes in staphylococci (Continued)

\begin{tabular}{lllllllllll}
\hline $\mathrm{S} 10$ & - & - & - & 4 & + & - & - & - & + & Oxa $^{\mathrm{R}}, \mathrm{Ery}^{\mathrm{R}}$ \\
$\mathrm{S} 13$ & + & + & - & 8 & + & - & - & - & + & Oxa $^{\mathrm{S}}, \mathrm{Ery}^{\mathrm{S}}$ \\
$\mathrm{S} 24$ & + & + & + & 16 & + & - & - & - & + & Ery $^{\mathrm{R}}$ \\
$\mathrm{S} 39$ & + & - & + & 16 & + & + & - & + & - & Oxa $^{\mathrm{R}}, \mathrm{Ery}^{\mathrm{R}}$ \\
$\mathrm{S} 42$ & + & - & + & 16 & + & - & + & - & + & Oxa $^{\mathrm{R}}, \mathrm{Ery}^{\mathrm{R}}$ \\
$\mathrm{S} 8$ & - & - & - & 8 & + & - & - & - & - & Oxa $^{\mathrm{R}}, \mathrm{Ery}^{\mathrm{R}}$ \\
\hline
\end{tabular}

+ , presence of the gene -, absence of the gene; $O \mathrm{xa}^{\mathrm{R}}$, oxacillin resistance; Oxa ${ }^{\mathrm{S}}$, oxacillin susceptible; $\mathrm{BC}^{\mathrm{b}}, \mathrm{MIC}$ of benzalchonium chloride $\mu \mathrm{g} / \mathrm{ml}$.

Table 3 Distribution of disinfectant and macrolide resistance genes in staphylococci

\begin{tabular}{|c|c|c|c|c|c|c|c|c|c|c|c|}
\hline Species & Samples & qacA & $q a c B$ & qacC & $\mathrm{BC}^{\mathrm{b}}$ & mecA & ermA & erm $B$ & ermC & $m s r A$ & Antibiotic \\
\hline \multirow[t]{5}{*}{ S. warnerie } & S11 & - & - & + & 8 & + & - & - & + & + & Oxas, Ery $^{\mathrm{S}}$ \\
\hline & S14 & - & - & - & 2 & - & - & - & - & + & $\mathrm{Oxa}^{\mathrm{S}}, \mathrm{Ery}^{\mathrm{S}}$ \\
\hline & $\$ 29$ & - & + & - & 8 & - & - & - & - & + & Oxas ${ }^{\mathrm{S}}$ Ery ${ }^{\mathrm{S}}$ \\
\hline & S37 & - & - & + & 8 & + & - & - & + & + & Oxa ${ }^{\mathrm{S}}, \mathrm{Ery}^{\mathrm{S}}$ \\
\hline & $\$ 47$ & - & + & - & 4 & + & + & + & + & + & Oxas ${ }^{\mathrm{S}}$ Ery ${ }^{\mathrm{S}}$ \\
\hline \multirow[t]{3}{*}{ S. chromogene } & $\mathrm{S} 30$ & + & - & + & 16 & + & - & - & + & + & Ery $^{R}$ \\
\hline & S32 & - & - & - & 2 & - & - & - & - & + & Oxa ${ }^{\mathrm{S}}, \mathrm{Ery}^{\mathrm{S}}$ \\
\hline & S51 & - & - & - & 2 & - & - & - & - & - & Ery $^{R}$ \\
\hline \multirow[t]{6}{*}{ S. simulans } & E23 & - & - & + & 4 & + & + & - & + & - & Ery $^{\mathrm{R}}$ \\
\hline & S19 & + & - & + & 16 & + & - & - & + & - & Oxa ${ }^{\mathrm{R}}$, Ery $^{\mathrm{R}}$ \\
\hline & $\mathrm{S} 20$ & - & - & - & 4 & + & - & - & - & + & Oxas ${ }^{\mathrm{S}}$ Ery ${ }^{\mathrm{S}}$ \\
\hline & $\mathrm{S} 28$ & + & + & + & 32 & + & + & - & + & + & $\mathrm{Oxa}^{\mathrm{R}}, \mathrm{Ery}^{\mathrm{R}}$ \\
\hline & S36 & + & - & - & 8 & + & - & - & - & - & Oxa ${ }^{\mathrm{S}}, \mathrm{Ery}^{\mathrm{S}}$ \\
\hline & $\mathrm{S} 5$ & + & + & + & 16 & + & - & - & + & - & $O x a^{R}$ \\
\hline \multirow[t]{27}{*}{ S.aureus } & Sa1 & - & - & + & 8 & + & + & + & - & - & Oxa ${ }^{\mathrm{R}}$, Ery $^{\mathrm{R}}$ \\
\hline & $\mathrm{Sa} 2$ & - & - & - & 4 & - & - & - & - & - & Oxas ${ }^{\mathrm{S}}$ Ery ${ }^{\mathrm{S}}$ \\
\hline & Sa3 & - & - & - & 8 & - & - & + & - & - & Oxa ${ }^{\mathrm{S}}, \mathrm{Ery}^{\mathrm{s}}$ \\
\hline & Sa4 & - & - & - & 4 & - & - & - & - & - & Oxa ${ }^{\mathrm{S}}, \mathrm{Ery}^{\mathrm{S}}$ \\
\hline & Sa5 & + & + & - & 8 & - & + & - & + & + & Oxas ${ }^{\mathrm{s}}$, Ery $^{\mathrm{s}}$ \\
\hline & Sa6 & & - & - & 8 & - & - & & - & & $\mathrm{Oxa}^{\mathrm{S}}, \mathrm{Ery}^{\mathrm{S}}$ \\
\hline & Sa7 & - & - & - & 4 & - & - & - & - & - & Oxa ${ }^{\mathrm{S}}, \mathrm{Ery}^{\mathrm{S}}$ \\
\hline & Sa8 & - & - & - & 8 & + & - & + & - & + & Oxa ${ }^{R}$, Ery $^{R}$ \\
\hline & Sa9 & - & - & - & 2 & - & - & - & + & - & Oxa ${ }^{\mathrm{S}}, \mathrm{Ery}^{\mathrm{S}}$ \\
\hline & Sa10 & + & + & - & 8 & + & - & + & - & - & Ery $^{R}$ \\
\hline & Sa11 & - & - & - & 4 & + & - & + & - & + & Ery $^{\mathrm{R}}$ \\
\hline & Sa12 & - & - & - & 8 & + & - & + & - & + & Ery $^{R}$ \\
\hline & Sa13 & - & - & - & 8 & + & - & + & - & - & $\mathrm{Oxa}^{\mathrm{S}}, \mathrm{Ery}^{\mathrm{s}}$ \\
\hline & Sa14 & - & - & - & 4 & + & - & - & - & - & $O x a^{R}$ \\
\hline & Sa15 & - & - & - & 8 & + & + & + & + & + & Oxas ${ }^{\mathrm{S}}$ Ery ${ }^{\mathrm{S}}$ \\
\hline & Sa16 & - & - & - & 4 & + & - & - & - & - & $O x a^{R}$ \\
\hline & Sa17 & - & - & - & 2 & - & - & - & - & + & Ery $^{\mathrm{R}}$ \\
\hline & Sa18 & - & - & - & 2 & - & + & + & - & - & Oxas ${ }^{\mathrm{S}}$ Ery ${ }^{\mathrm{S}}$ \\
\hline & Sa19 & + & - & + & 8 & - & - & + & - & - & Oxas ${ }^{\mathrm{S}}, \mathrm{Ery}^{\mathrm{S}}$ \\
\hline & $\mathrm{Sa} 20$ & + & - & + & 4 & - & + & + & + & + & $\mathrm{Oxa}^{\mathrm{S}}, \mathrm{Ery}^{\mathrm{S}}$ \\
\hline & Sa21 & - & - & - & 16 & - & - & + & - & - & Oxas Ery $^{\mathrm{S}}$ \\
\hline & Sa22 & + & + & + & 16 & + & - & - & + & - & Oxa ${ }^{R}$, Ery $^{R}$, \\
\hline & Sa23 & + & + & + & 16 & + & + & + & + & + & Oxa ${ }^{\mathrm{R}}$, Ery $^{\mathrm{R}}$ \\
\hline & Sa24 & - & - & - & 4 & - & - & - & - & - & Ery $^{R}$ \\
\hline & Sa25 & - & - & - & 4 & - & - & - & - & - & Oxa ${ }^{\mathrm{S}}, \mathrm{Ery}^{\mathrm{S}}$ \\
\hline & Sa26 & - & - & - & 4 & + & - & - & - & + & Oxa $^{\mathrm{R}}$, Ery $^{\mathrm{R}}$ \\
\hline & Sa27 & - & - & - & 2 & + & + & - & - & + & Oxa ${ }^{R}$, Ery $^{\mathrm{R}}$ \\
\hline
\end{tabular}




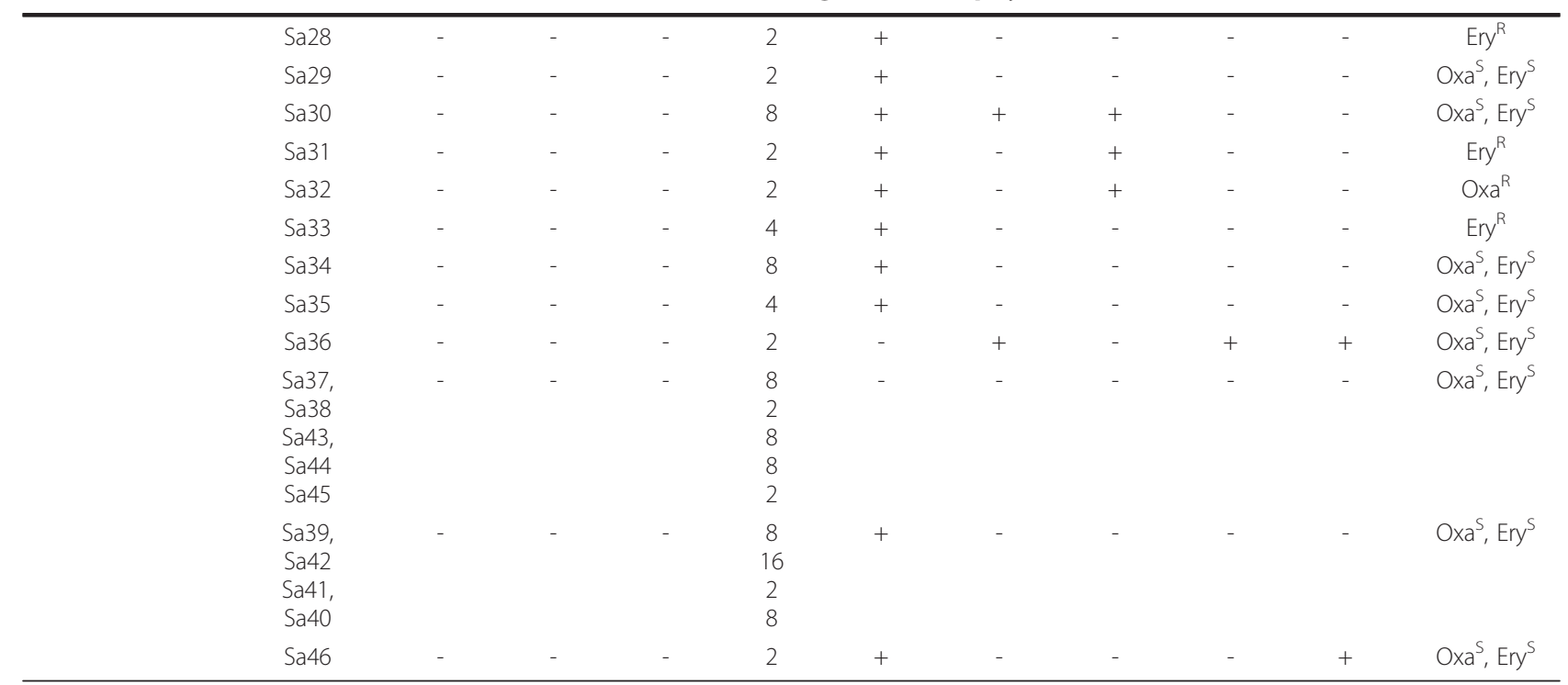

+ , presence of the gene -, absence of the gene; $\mathrm{Oxa}^{\mathrm{R}}$, oxacillin resistance; $\mathrm{Oxa}^{\mathrm{S}}$, oxacillin susceptible; $\mathrm{BC}^{\mathrm{b}}$, MIC of benzalchonium chloride $\mu \mathrm{g} / \mathrm{ml}$.

(Figure 3). While, nine CoNS strains, contained the three $q a c$ genes ( $q a c \mathrm{~A}, q a c \mathrm{~B}$ and $q a c \mathrm{C})$. In addition, qacC was the most present (35\%), followed by qacA (24\%), and $q a c B(15.4 \%)$ in the total of 117 isolated strains (Table 2 and 3).

Qac-resistant genes ( $q a c \mathrm{~A})$ were identified in $(5.12 \%)$ followed by qacC (4.27\%) and qacB (3.41\%) in the isolated S. aureus strains, while 39 (33\%) strains were qac-negative in the total of 117 isolated strains (Figure 4.). On the other hand, among the $32 \mathrm{~S}$. epidermidis strains under study, five were $q a c \mathrm{~A}_{+}$, two were $q a c \mathrm{~B}+$, and 16 were $q a c \mathrm{C}_{+}$, while 29 strains were qac-negative (Table 2 and 3). The three Qac-resistant genes ( $q a c \mathrm{~A}, q a c \mathrm{~B}$, and $q a c \mathrm{C}$ ) were identified in $9.4 \%$ of the total isolated strains. Nine strains (7.7\%) of six different CoNS species harboured the three qac-resistant genes.

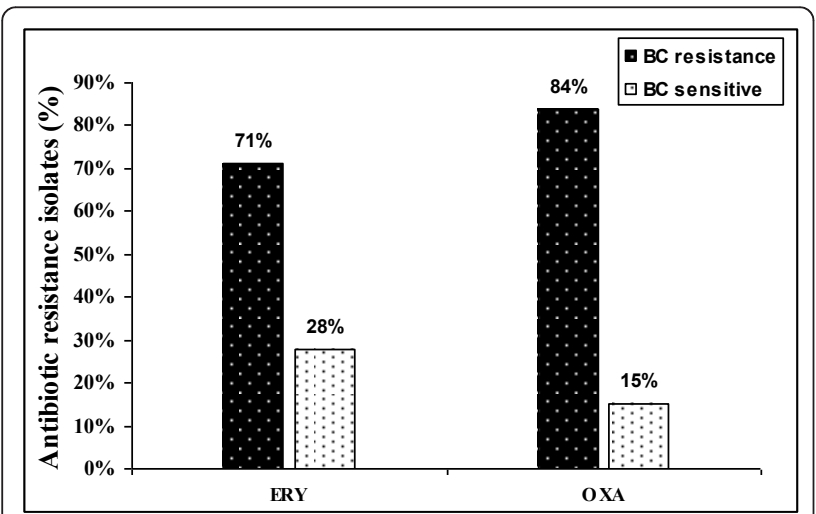

Figure 1 Percentages of antibiotic-resistance Staphylococci isolates among BC-resistance and BC-sensitive isolates. Antibiotics used are erythromycin (ERY) and oxacillin (OXA).

\section{Discussion}

Recently, the increasing numbers of device-related infections associated with methicillin-resistant staphylococci have raised awareness toward the need for alternative agents to prevent these infections. S. epidermidis species represent the CoNS most recovered from clinical specimens [3]. Among the 71 CoNS isolated in this study, the most prevalent were $S$. epidermidis $(\mathrm{n}=32)$, S. hominis $(\mathrm{n}=10)$, and $S$. haemolyticus $(\mathrm{n}=9)$. The antibiotic susceptibility of the 117 staphylococal (S.aureus and CoNS) isolated in this study confirmed the multi-resistance of these strains toward the 18 antibiotics cited previously. Oxacillin resistance occurred in $7.7 \%$ of $S$. aureus and in 20.5\% of CoNS tested by ATB Staph.

Erythromycin resistance in staphylococci is predominantly mediated by erythromycin-resistant methylase encoded by erm genes [27]. The inducible gene $\mathrm{erm} A$ is found on the transposon Tn554 and has a single specific site for insertion into the $S$. aureus chromosome [28]. The ermB gene is found on the transposon Tn551 of a penicillinase plasmid [29]. The ermC gene is responsible for constitutive or inducible resistance to erythromycin and is generally located on small plasmids $[5,27,30]$. On the other hand, the investigation of the prevalence of ermA, erm $\mathrm{B}$, erm $\mathrm{C}$ and $m s r \mathrm{~A}$ genes in Staphylococci showed that only 28 strains of $S$. aureus $(\mathrm{n}=46)$ and CoNS $(\mathrm{n}=71)$ were found to be susceptible to erythromycin, yet contained erythromycin-resistant gene, and 44 strains (13 S. aureus and 31 CoNS) have at least one of the four genes $(\operatorname{erm} A, \operatorname{erm} B, \operatorname{erm} C$ and $m s r A)$ and were susceptible to erythromycin. Similarly, Sekiguchi et al. [26] found discordance among phenotypic susceptibility and the presence of erm genes. They stated that this discordance might be 


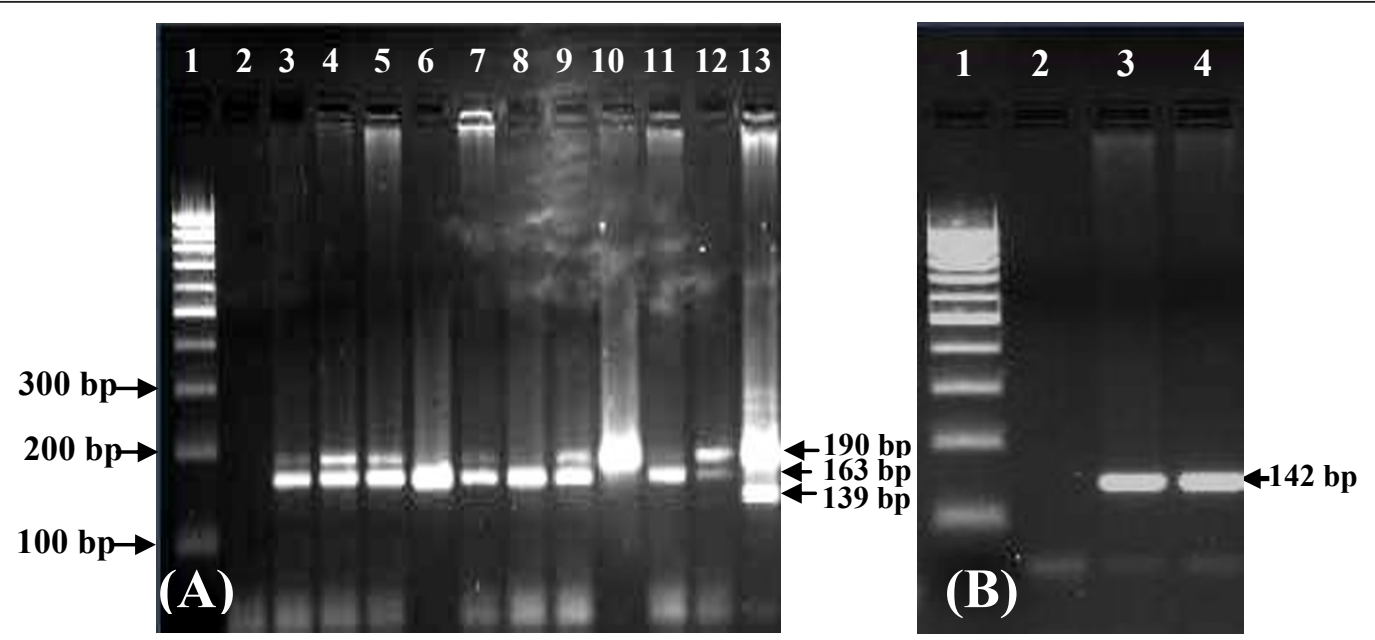

Figure 2 (A) PCR analysis of erythromycin-resistant determinants: ermA (139 bp), msrA (163 bp) and ermC (190 bp) with clinical strains; source of DNA: 1: 100 bp DNA molecular size marker; 2: negative control; 3: S16; 4: E6; 5: E18; 6: S40; 7: E24; 8: E20; 9: S22; 10: S12; 11: S9; 12: S21 and 13: E15. (B) Agarose gel electrophoresis of PCR amplicon of erythromycin-resistant ermB gene (142 bp) obtained with DNA of clinical strains; 1: 100 bp DNA molecular size marker; 2: negative control; 3: E10 and 4: E11.

due to a mutation in the coding or promoter region of the PCR-detected genes. We noted also that eight strains of $S$. aureus and CoNS strains were found to be resistant to erythromycin but did not carry any erythromycin resistance gene (Table 1 and 2). This result may be explained by the location of these genes in small plasmids, which were occasionally lost. Fluit et al. [31] demonstrated that the erm $\mathrm{C}$ gene responsible for erythromycin resistance is located on a small plasmid. In this study, the incidences of ermA in erythromycin-resistant staphylococci were $7.7 \%$ for S. aureus and 3.4\% for S. epidermidis. These findings are in disagreement with the study by Eady et al. [5] conducted with coagulase-negative staphylococci (CoNS) in the United Kingdom in which an incidence of 5.9\% for ermA was reported. In a study performed in Denmark,

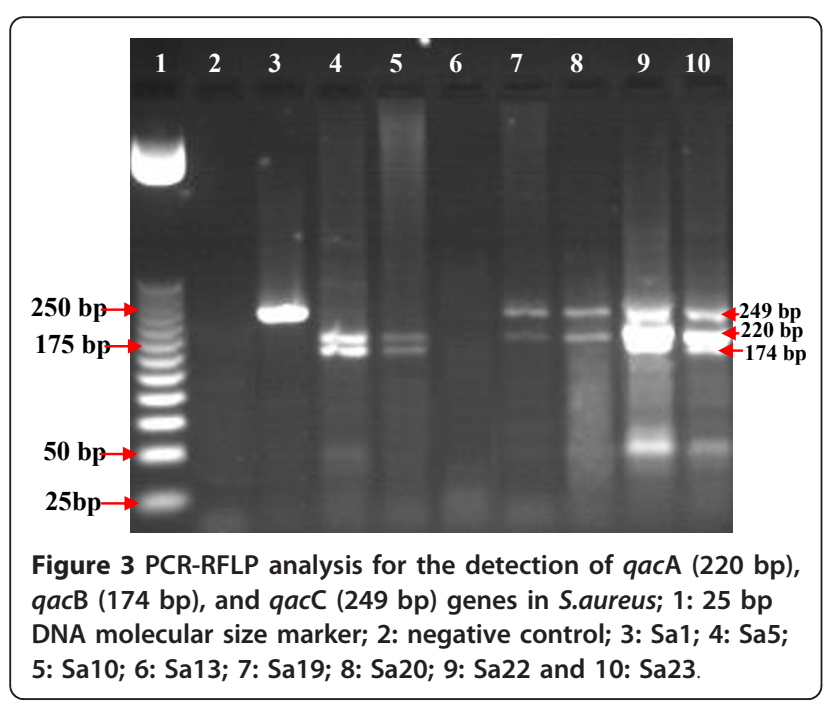

$16 \%$ of $S$. aureus strains were carrying ermA, while only $3 \%$ of CoNS strains had this gene [30]. Regarding ermB, we found that this gene was more frequently encountered than ermA in erythromycin-resistant staphylococci with $24.8 \%$ (13.7\% for S.aureus and 11\% for CoNS) of total strains carrying ermB. In the United Kingdom, an incidence of 7.2\% for ermB in CoNS has been reported [5]. Staphylococcal strains resistant to macrolides and type-B streptogramins frequently harbour $m s r \mathrm{~A}$, which encodes an ATP-dependent efflux pump [5]. Erythromycin resistance may be caused by the msr A or ermB gene, as previously reported with staphylococci [5]. Our results are similar to those of a recent study investigating a high level of ermA and ermC genes in CoNS [32].

Staphylococcal multidrug-resistant gene qacA is generally mediated by plasmids mediated resistance to various toxic organic cations and ethidium bromide, as well

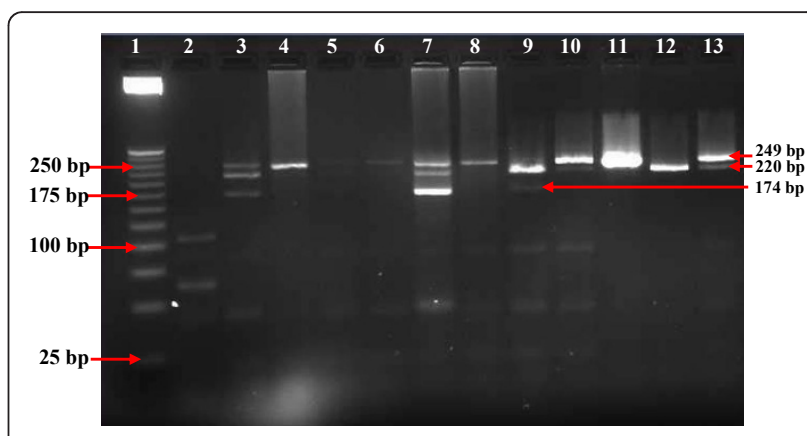

Figure 4 PCR-RFLP analysis for the detection of qacA (220 bp), qacB (174 bp), and qacC (249 bp) in CoNS; 1: 25 bp DNA molecular size marker; 2: negative control; 3: S9; 4: E15; 5: E13; 6: E6; 7: S18; 8: E7; 9: S13; 10: S19; 11: S11; 12: S45 and 13: S39. 
as a number of commonly used antiseptics and disinfectants, such as benzalkonium chloride and chlorhexidine [19]. The qacA gene also encodes resistance to both monovalent and divalent organic cations. In addition, $q a c \mathrm{~B}$ characteristically differs from qacA by conferring lower or no resistance to divalent organic cations [33]. Some investigations have implied that there is disinfectant cross-resistance with antibiotics [34,35].

Among the tested bacteria, 2 strains of S.aureus and 9 strains of CoNS carried the three qac genes (qacA, qacB, and $q a c \mathrm{C}$ ), as shown in Table 1 and 2. QacC gene was the most present in the 117 isolated strains (35\%), followed by qacA (24\%), and qacB (15. 4\%). Of the 117 isolates investigated in this study, $74 \%$ were phenotypically resistant to BC. $56 \%$ of the BC-resistant staphylococcus isolates have at least one of the three resistant disinfectants genes ( $q a c A / B$ and $q a c C)$. Previous investigators have reported a similar distribution of these three qac resistance genes in clinical S. aureus and CoNS [36,15]. Little is known about the occurrence and possible genetic linkage of $q a c$ and antibiotic resistance in staphylococci. Interestingly, we observed that staphylococci resistant to $\mathrm{BC}$ were generally more often resistant to antibiotics (Ery and Oxa) than BCsensitive isolates (Figure 1).

Furthermore, among the nine MRSA isolates, two strains (Sa22 and Sa23) were multi-resistant to antibiotic and harboured the qac genes. MRSA isolates resistant to antiseptics and disinfectants have been reported in Australia and in United Kingdom in the last decade [8]. Sekiguchi et al., [26] have found that among the 65 MRSA isolates 32 (49.23\%) were positive for qacA, while one isolate was positive for $q a c \mathrm{~B}$ and seven MRSA $10 \%$ were positive for qacC. Three strains of S. hemolyticus harboured qacA and qacB genes. In a recent study, S. hemolyticus isolates were shown to contain both qacA and qacB genes [37]. QacA/B genes are typically located on a transposon of transmissible multidrug-resistant plasmids, such as pSK1 [33]. Staphylococci resistant genes to quaternary ammonium compounds (QACs) have been detected in clinical coagulase-negative staphylococci [36]. QAC resistant Staphylococcus spp. hosting qacA/qacB and $s m r$ have been isolated from different environments [38]. Results from a recent study in Norway suggest that qac-resistant genes are common in human clinical staphylococci and that a direct link between resistance to QACs and resistance to penicillin occurs in clinical isolates of human and animal origin as well as in foodrelated staphylococci $[11,22]$. Noguchi et al. [16] reported that when the antiseptic susceptibility and the distribution of antiseptic-resistant genes of MRSA isolated in Japan in 1992 were studied, qacA/B were detected in $10.2 \%$ (10/98). However, seven years later, qacA/B genes were detected in $47.9 \%(198 / 413)$ in MRSA isolates in Japan.

\section{Conclusion}

It appears that the widespread distribution of staphylococci carrying macrolides and qac-resistant genes found in dialysis biomaterial collected in Tunisia may be due to the transfer of resistance plasmids among species and strains, thereby contributing to the dissemination of staphylococcal resistance. Therefore, a closer investigation of antibiotics and antiseptic-resistant CoNS may provide crucial information on the control of nosocomial infections.

\section{Authors' contributions}

TZ was the primary author of the manuscript, assisted in samples collection, antimicrobial susceptibility, detection of resistance genes and assisted in minimum inhibition concentration determination of BC. BK contributed in minimum inhibition concentration determination, assisted in detection of resistance genes and helped in the writing of the manuscript. HM participated in detection of resistance genes, data acquisition and contributed in writing of the manuscript. $A B$ provided funding, supervised the study, and helped to finalize the manuscript.

All authors read and approved the final manuscript

\section{Competing interests}

The authors declare that they have no competing interests.

Received: 2 August 2011 Accepted: 27 October 2011

Published: 27 October 2011

\section{References}

1. Hiramatsu K: Vancomycin resistance in staphylococci. Drug Resist Updat 1998, 1:135-150.

2. Brun-Buisson $\mathrm{CH}$ : Les Staphylococcus aureus résistants à la méticilline: Evolution et épidémiologie, impact clinique, prévention. Pathol Biol 1998, 46:227-34.

3. Kloos WE, Bannerman TL: Update on clinical significance of coagulasenegative staphylococci. Clin Microbiol Rev 1994, 7:117-140.

4. Neely AN, Maley MP: Survival of enterococci and staphylococci on hospital fabrics and plastic. J Clin Microbiol 2000, 38:724-726.

5. Eady EA, Ross Jl, Tipper JL, Walters CE, Cove JH, Noble WC: Distribution of genes encoding erythromycin ribosomal methylases and an erythromycin efflux pump in epidemiologically distinct groups of staphylococci. J Antimicrob Chemother 1993, 31:211-7.

6. Ross Jl, Eady EA, Cove JH, Baumberg S: Identification of a chromosomally encoded $A B C$-transport system with which the staphylococcal erythromycin exporter MsrA may interact. Gene 1995, 153:93-98.

7. Leclercq R: Mechanisms of resistance to macrolides and lincosamides: nature of the resistance elements and their clinical implications. Clin Infect Dis 2002, 34:482-492.

8. McDonnell G, Russell AD: Antiseptics and disinfectants: activity, action, and resistance. Clin Microbiol Rev 1999, 12:147-179.

9. Reverdy $M E$, Bes M, Brun Y, Fleurette J: Evolution of resistance to antibiotics and antiseptics of hospital Staphylococcus aureus strains isolated from 1980 to 1991. Pathol Biol 1993, 41:897-904.

10. Russell AD: Do biocides select for antibiotic resistance? J Pharm Pharmacol 2000, 52:227-233.

11. Anthonisen IL, Sunde M, Steinum TM, Sidhu MS, Sorum H: Organization of the antiseptic resistance gene qacA and Tn552-related ßlactamase genes in multidrug-resistant Staphylococcus haemolyticus strains of animal and human origins. Antimicrob. Agents Chemother 2002, 46:3606-3612.

12. Bjorland J, Steinum T, Sunde M, Waage S, Heir E: Novel plasmid-borne gene qacJ mediates resistance to quaternary ammonium com pounds in equine Staphylococcus aureus, Staphylococcus simulans, and Staphylococcus intermedius. Antimicrob Agents Chemother 2003, 47:3046-3052.

13. Heir E, Sundheim G, Holck AL: The qacG gene on plasmid pST94 confers resistance to quaternary ammonium compounds in staphylococci isolated from the food industry. J Appl Microbiol 1999, 86:378-388. 
14. Leelaporn A, Firth N, Paulsen IT, Hettiaratchi A, Skurray RA: Multidrug resistance plasmid pSK108 from coagulase-negative staphylococci; relationships to Staphylococcus aureus qacC plasmids. Plasmid 1995, 34:62-67.

15. Mayer S, Boos M, Beyer A, Fluit AC, Schmitz FJ: Distribution of the antiseptic resistance genes qacA, qacB and qacC in 497 methicillinresistant and susceptible European isolates of Staphylococcus aureus. J Antimicrob Chemother 2001, 47:896-897.

16. Noguchi N, Hase M, Kitta M, Sasatsu M, Deguchi K, Kono M: Antiseptic susceptibility and distribution of antiseptic-resistance genes in methicillin-resistant Staphylococcus aureus. FEMS Microbiol Lett 1999, 172:247-253.

17. Berg T, Firth N, Apisiridej S, Hettiaratchi A, Leelaporn A, Skurray RA: Complete nucleotide sequence of pSK41:evolution of staphylococcal conjugative multiresistance plasmids. J Bacteriol 1998, 180:4350-4359.

18. Sidhu MS, Heir E, Sorum H, Holck A: Genetic linkage between resistance to quaternary ammonium compounds and $\beta$ lactam antibiotics in foodrelated Staphylococccus spp. Microb Drug Resis 2001, 7:363-371.

19. Littlejohn TG, Paulsen IT, Gillespie MT, Tennent JM, Midgley M, Jones IG, Purewal AS, Skurray RA: Substrate specificity and energetics of antiseptic and disinfectant resistance in Staphylococcus aureus. FEMS Microbiol Lett 1992, 74:259-265.

20. Littlejohn TG, DiBerardino D, Messerotti LJ, Spiers SJ, Skurray RA: Structure and evolution of a family of genes encoding antiseptic and disinfectant resistance in Staphylococcus aureus. Gene 1991, 101:59-66.

21. Paulsen IT, Brown MH, Dunstan SJ, Skurray RA: Molecular characterization of the staphylococcal multidrug resistance export protein QacC. J Bacteriol 1995, 177:2827-2833.

22. Sidhu MS, Heir E, Leegaard T, Wiger K, Holck A: Frequency of disinfectant resistance genes and genetic linkage with ßlactamase transposon Tn552 among clinical staphylococci. Antimicrob Agents Chemother 2002, 46:2797-2803.

23. CLSI: Methods for Dilution Antimicrobial Susceptibility Tests for Bacteria That Grow Aerobically. Approved Standard-Seventh Edition CLSI Document M7-A7 2006

24. Martineau F, Picard FJ, Lansac N, Ménard C, Roy PH, Ouellette M, Bergeron MG: Correlation between the resistance genotype determined by multiplex PCR assays and the antibiotic susceptibility patterns of Staphylococcus aureus and Staphylococcus epidermidis. Antimicrob Agents Chemother 2000, 231-238.

25. Lim JA, Kwon AR, Kim SK, Chong Y, Lee K, Choi EC: Prevalence of resistance to macrolide, lincosamide and streptogramin antibiotics in Gram-positive cocci isolated in a Korean hospital. J Antimicrob Chemother 2002, 49:489-95.

26. Sekiguchi J, Hama T, Fujino T, Araake M, Irie A, Saruta $K$, et al: Detection of the antiseptic- and disinfectant-resistance genes qacA, qacB, and qacC in methicillin-resistant Staphylococcus aureus isolated in a Tokyo hospital. Jpn J Infect Dis 2004, 57:288-91.

27. Weisblum B: Erythromycin resistance by ribosome modification Antimicrob Agents Chemother 1995, 39:577-585.

28. Murphy E: Nucleotide sequence of ermA, a macrolide-lincosamide streptogramin B determinant in Staphylococcus aureus. J Bacteriol 1985, 162:633-640.

29. Khan SA, Novick RP: Terminal nucleotide sequences of $\operatorname{Tn} 551$, a transposon specifying erythromycin resistance in Staphylococcus aureus: homology with Tn3. Plasmid 1980, 4:148-154.

30. Westh H, Hougaard DM, Vuust J, Rosdahl VT: Erm genes in erythromycinresistant Staphylococcus aureus and coagulase-negative staphylococci. APMIS 1995, 103:225-232.

31. Fluit ADC, Visser MR, Schmitz F: Molecular detection of antimicrobial resistance. Clin Microbiol Rev 2001, 14:836-871.

32. Ardic N, Ozyurt M, Sareyyupoglu B, Haznedaroglu T: Investigation of erythromycin and tetracycline resistance genes in methicillin-resistant staphylococci. Int J Antimicrob Agents 2005, 26:213-218.

33. Lyon BR, Skurray RA: Antimicrobial resistance of Staphylococcus aureus: genetic basis. Microbiol Rev 1987, 51:88-134.

34. Schweizer HP: Triclosan: a widely used biocide and its link to antibiotics. FEMS Microbiol Lett 2001, 202:1-7.

35. Chapman S: Disinfectant resistance mechanisms, cross-resistance and coresistance. Int Biodeterior Biodegrad 2003, 51:271-276.
36. Leelaporn A, Paulsen IT, Tennent JM, Littlejohn TG, Skurray RA: Multidrug resistance to antiseptics and disinfectants in coagulase-negative staphylococci. J Med Microbiol 1994, 40:214-220.

37. Bjorland J, Steinum T, Kvitle B, Waage S, Sunde M, Heir E: Widespread Distribution of Disinfectant Resistance Genes among Staphylococci of Bovine and Caprine Origin in Norway. J Clin Microbiol 2005, 43:63-4368.

38. Heir E, Sundheim G, Holck AL: Resistance to quaternary ammonium compounds in Staphylococcus spp. Isolated from the food industry and nucleotide sequence of the resistance plasmid pST827. J Appl Bacteriol 1995, 79:149-156.

doi:10.1186/1756-0500-4-453

Cite this article as: Zmantar et al:: Detection of macrolide and disinfectant resistance genes in clinical Staphylococcus aureus and coagulase-negative staphylococci. BMC Research Notes 2011 4:453.

\section{Submit your next manuscript to BioMed Central and take full advantage of:}

- Convenient online submission

- Thorough peer review

- No space constraints or color figure charges

- Immediate publication on acceptance

- Inclusion in PubMed, CAS, Scopus and Google Scholar

- Research which is freely available for redistribution

Submit your manuscript at www.biomedcentral.com/submit
Biomed Central 